\title{
SUBSURFACE STRUCTURAL SETTING OF AL AMIR AND GEYAD FIELDS, SOUTHWESTERN PART OF THE GULF OF SUEZ RIFT, EGYPT
}

\author{
Ahmed A. Mayhoub ${ }^{1}$, Adel R. Moustafa ${ }^{2}$, Mohamed Yousef ${ }^{2}$, and Samir M. Zalat ${ }^{3}$ \\ ${ }^{1}$ EREX, Egypt; \\ ${ }^{2}$ Department of Geology, Ain Shams University, Cairo 11566, Egypt; \\ ${ }^{3}$ PetroAmir, Cairo, Egypt
}

\begin{abstract}
The study area is located within the southern dip province of the Gulf of Suez rift and includes two oil fields, Al Amir and Geyad. This area is located to the west of Gebel El Zeit and covers an area of about $321 \mathrm{~km}^{2}$. The study is based on the analysis of seismic and borehole data. Six Miocene seismic horizons are mapped from Top Zeit down to top Nukhul Formation. The study area is characterized by SW dip direction and is dissected by major NW-SE oriented, rift-parallel faults and some NE-SW oriented cross faults creating the two blocks of Al Amir and Geyad oil fields. The study shows the effect of these faults on the distribution of the clastic reservoir of the Kareem Formation.
\end{abstract}

Keywords: Gulf of Suez rifts, Al Amir and Geyad oil fields, cross faults.

\section{Introduction}

The West-Zeit (Gemsa) sub-basin is bounded from the east by the promontory of Gebel El-Zeit Precambrian basement and from the west by Esh El Mellaha range that is dominated by metavolcanics, metamorphic and granitic Precambrian rocks (Figure 1). This sub-basin is a SW-dipping half graben bounded by Esh El Mellaha major fault on the southwest and the Gebel El Zeit fault on the northeast. It is bounded on the north by the Morgan accommodation Zone that separates the NE and SW dipping half grabens of the central and southern parts of the Gulf of Suez rift. The Al Amir and Geyad oil fields lie in the central part of the sub-basin with reservoir sections in the Kareem Formation below the South Gharib and Belayim evaporite sections. The objective of this study is to delineate the structural setting of the two fields and its relationship to the rift as well as the effect of the structures on the reservoir distribution. 


\section{Data and Methodology}

The data used for this study includes seismic and borehole data. The seismic data include four vintages of 2D land seismic surveys; approximately $321 \mathrm{~km}$ total length. Nine wells are used, these are (from north to south) Shehab-1X, Geyad-2X, Geyad-1X, Al Amir SE-1X\&st, Al Amir SE-2X, Al Amir SE-3X, Al Amir SE-4X, Al Amir SE-5X and Al Amir SE-6X (Figure 1). The used $\operatorname{logs}$ are Sonic, Neutron and Density where synthetic seismograms were constructed for Al Amir SE-1X ST, Al Amir SE-2X and Al Amir SE-3X wells and were used for horizon identification. Six seismic horizons are picked; namely from top to bottom, Top Zeit Formation, Top South Gharib Formation, Top Belayim Formation, Top Kareem Formation, Top Rudeis Formation and Top Nukhul Formation. Time-structural maps have been converted to depth and have been used for studying the structural setting of the area.

\section{Geological setting of the Gulf of Suez rift}

The tectono-stratigraphic setting of the Gulf of Suez rift has been analyzed by eminent workers since the early discoveries of oil at Gemsa field in 1886 (Dolson et al., 2000). The main studies include the works of Moon and Sadek (1923), NSSC National Stratigraphic subcommittee (1964 and 1974), Moustafa (1976), Colletta et al. (1985), Moustafa and Fouda (1988), Moustafa (1993), Patton et al. (1994), McClay et al. (1998), Moustafa (2002), among others. The Gulf of Suez rift includes three mega half grabens, with opposite dip polarities separated by two accommodation zones. The northern and southern half grabens have SW dip whereas the central half graben has NE dip. The study area is located in the western part of the southern half graben. Four dominant fault trends are obvious in the rift and an oriented NNW-SSE (most dominant and rift-parallel), NNE-SSW, WNW-ESE, and ENE-WSW (cross faults). Opening of the Gulf of Suez rift was during the Oligo-Miocene to Early Miocene time leading to deposition of syn-rift Miocene sediments in half graben basins. Rifting was aborted in Late Miocene time when the Dead Sea transform became active and separated the Gulf of Suez rift from the Red Sea.

\section{Stratigraphic setting of the Gulf of Suez area}

The Miocene rock units in the study area include, from base to top, the Nukhul, Rudeis, Kareem and Belayim formations below the main evaporite sequence of the South Gharib and Zeit formations (Figure 2). The Nukhul Formation is composed mainly of sandstone with shale and limestone interbeds at its lower part. The Rudeis Formation includes two main units, a lower unit (Mheiherat and Hawara Members) which consists of limestone in 
the base and marl beds at the top and an upper unit (Asl Member) which consists of shale and limestone. The Kareem Formation includes two main units, a Lower unit (Rahmi Member) which consists mainly of shaly limestone at the lower part with thin beds of anhydrite at the base and sandstone at the top and an upper unit (Shagar Member) which consists of shaly limestone and shale with limestone intercalations at the top. There is a sandstone unit in the lower part of the Kareem Formation and represents the main oil reservoir in the study area. The Belayim Formation includes anhydrite and salt of the Feiran and Baba Members with thin bodies of sandstone and shale in Sidri and Hammam Faraun Members. The Tortonian (10.4-6.4 Ma) South Gharib Formation consists of a very thick sequence of halite coincident with a major rapid global sea level drop (Haq et al., 1987). The Messinian (6.4-5.2 Ma) Zeit Formation is a dominantly sulphate evaporite sequence consisting of thin alternating beds of shale and anhydrite with occasional halite.

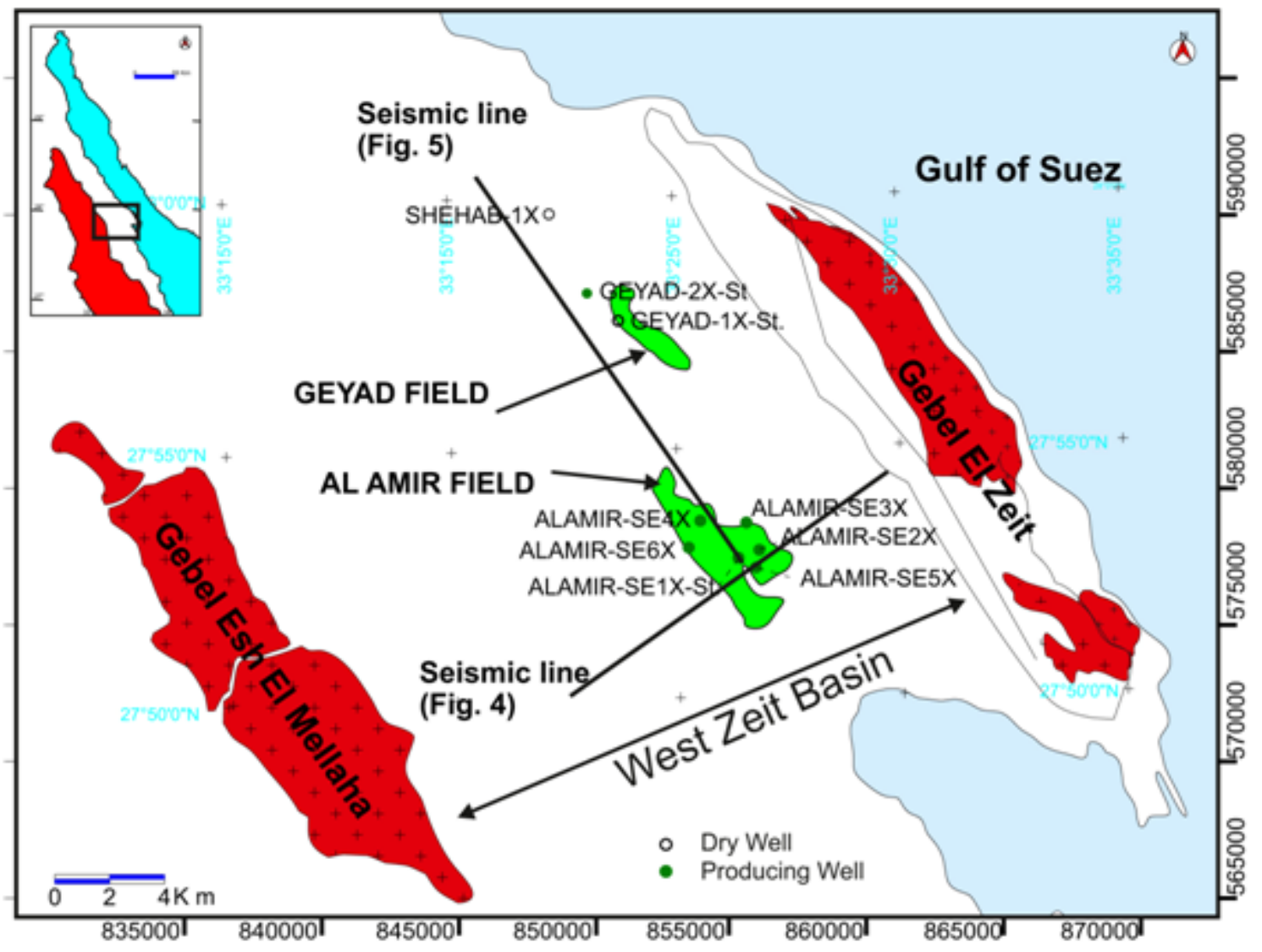

Fig. 1: Base map of the study area showing the used wells and the Al Amir and Geyad oil fields. Hachured areas represent the basement outcrops. 


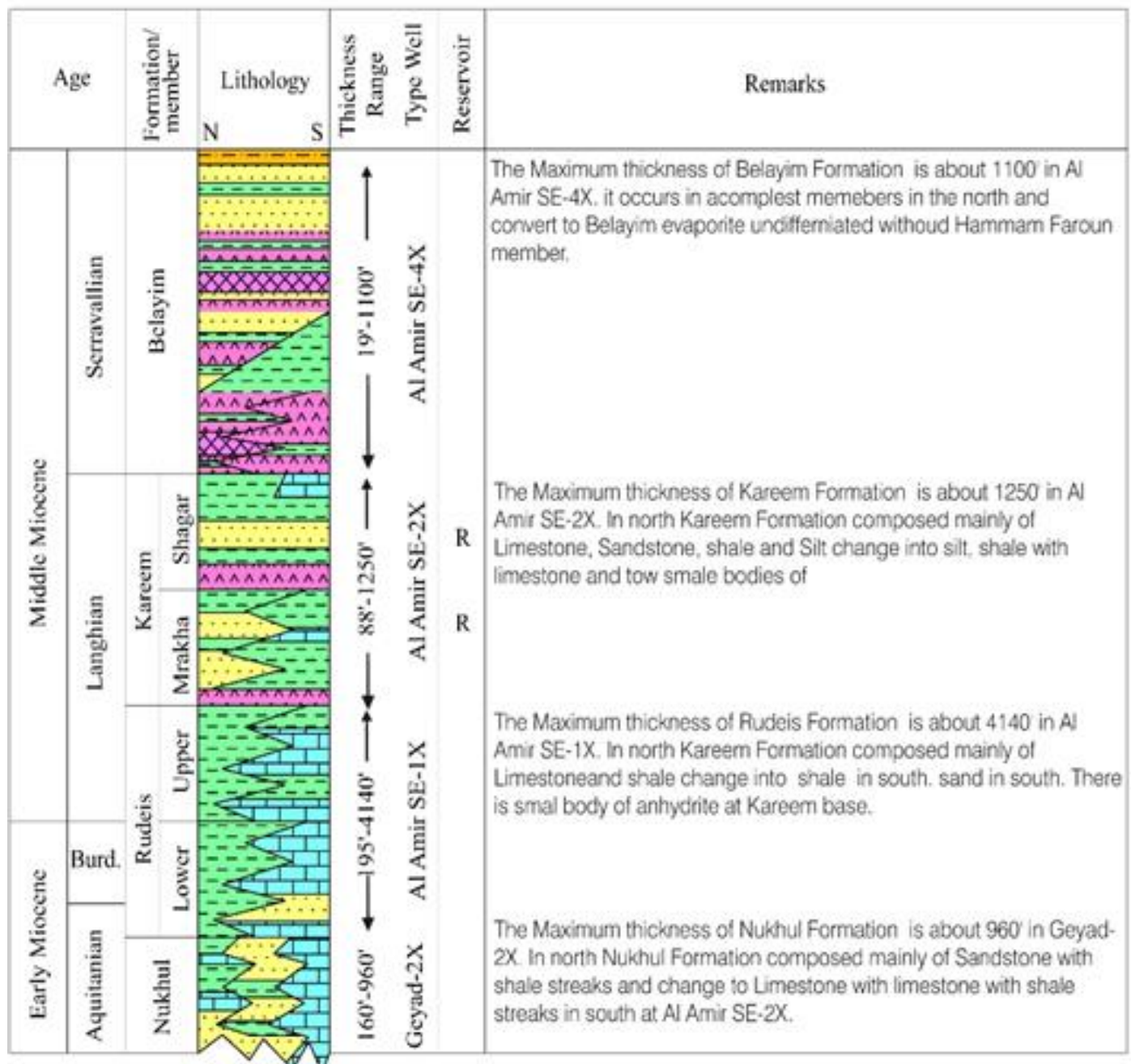

Fig. 2: Lihostratigraphic composite log of the main Miocene formations of the study area based on the data of the drilled wells.

\section{Structural setting of the study area}

The study area is bounded from the east side by Gebel El-Zeit, which is an elongated NW-SE oriented range, $86 \mathrm{Km}$ long and $5 \mathrm{Km}$ wide bordering the west coast of the Gulf of Suez (Figure 3). An incomplete pre-Miocene sequence is exposed at Gebel El Zeit (Evans, 1988; Darwish and El Araby, 1993; Sakran et al., 2015). To the west, Esh El Mellaha range shows southwest dip with an average dip angle of $6^{\circ}$ and is bounded on the west by NNW-SSE oriented normal fault and is downthrown relative to the adjacent Red Sea hills. The eastern side of Esh El Mellaha range is bounded by a major NNW-SSE oriented normal fault that frequently changes its strike along Precambrian basement. The northern ends of Gebel El Zeit and Esh El Mellaha are bounded by the Morgan accommodation zone where Sufr El Dara block includes folded pre-Miocene successions (Moustafa and Fouda, 1988). 


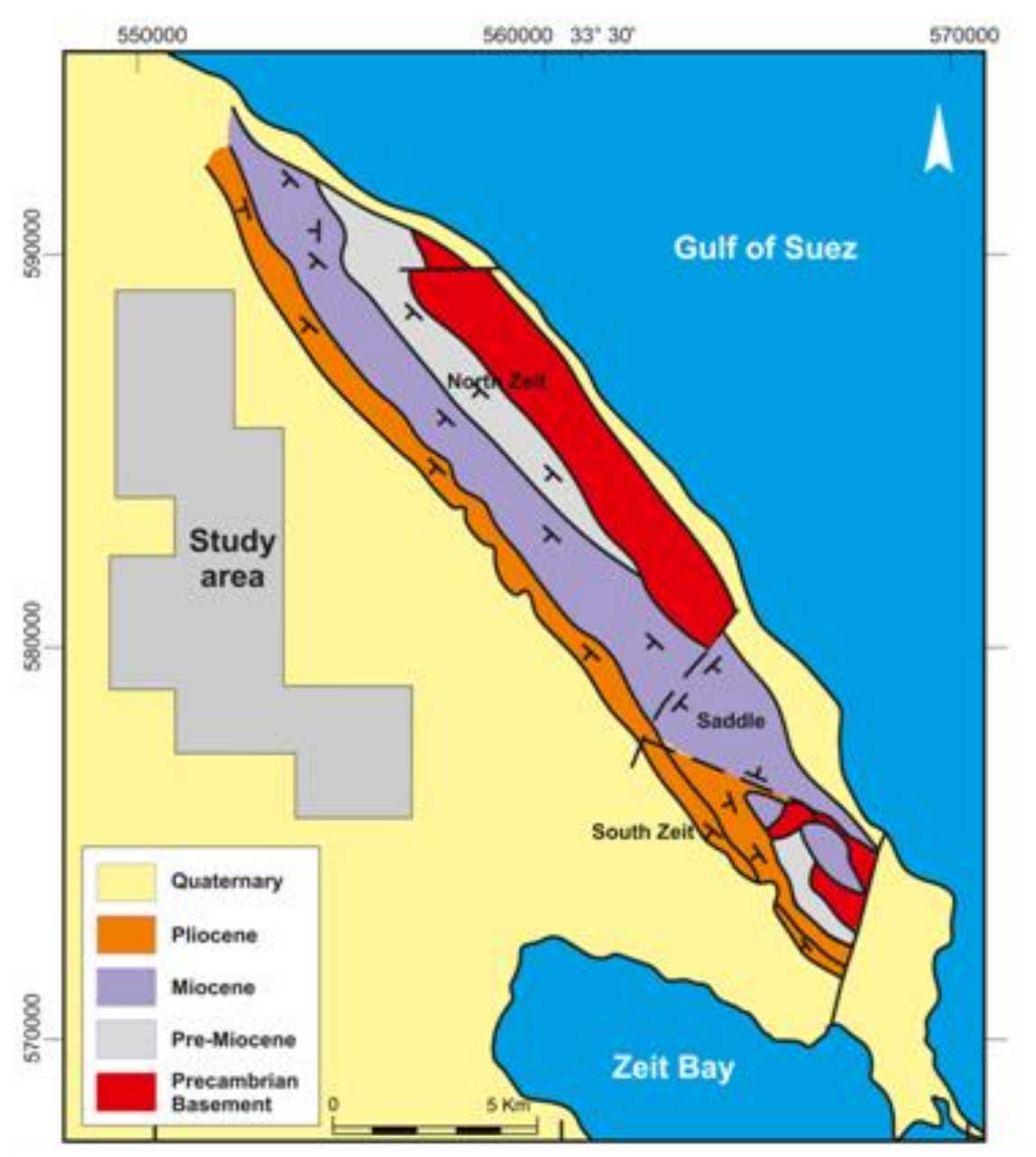

Fig. 3: Location map of the study area in relation to Gebel El-Zeit geology (after Evans and Moxon, 1986).

\section{Seismic Data Interpretation}

The seismic interpretation was carried out using Schlumberger ${ }^{\mathrm{TM}}$ Petrel software. Six Miocene horizons were picked as mentioned above and the resulting time-structural maps were depth converted. Two selected dip and strike sections are presented to illustrate the structural geometry of the mapped area (Figures 4 and 5). The depth structure contour map on the top Kareem Formation (Figure 6) is illustrated to represent the structural setting of the study area, where the main structural features are repeated for the other formations.

\section{Structural Geometry}

The seismic interpretation shows some normal faults dissecting SW inclined horizons. The faults have clysmic (NNW-SSE) trend in addition to some faults having cross (ENE-WSW) trend. Some faults dissect all Miocene rock units from Nukhul to top Zeit Formation whereas other faults die out within 
the Miocene section. Figure 4 shows a NE-SW oriented seismic section passing through Al Amir SE-5X well. It shows tilted fault blocks with dip direction toward the southwest, dissected by NNW-SSE oriented normal faults with downthrow toward the SW and NE directions, cutting the syn-rift sequence (from Nukhul to Zeit formations). Figure 4 also shows gradual thickening of the Miocene sediments toward the SW in the down dip direction indicating continuous SW tilting of the area during the Miocene time.

Figure 5 is NW-SE trending strike seismic section that passes near Gebel El Zeit-2, Al Mir SE-4X, Al Mir SE-1X and Al Mir SE-5X wells. Several NESW trending cross faults are obvious on this section dividing the study area into two blocks (I and II). Block I is a garben between two NE-SW trending normal faults. This garben is dragged by the southeastern bounding fault and shows a rollover anticline on the northwestern bounding fault. Block II is a SW tilted block lying between two NE-SW trending normal faults (Figure 5).

\section{Top Kareem Formation Depth Structure map}

The top Kareem Formation map (Figure 6) shows predominant SW direction of dip. This formation is dissected by several faults oriented NNW-SSE (riftparallel) and ENE-WSW (cross faults). Table 1 shows the maximum throws of these faults.

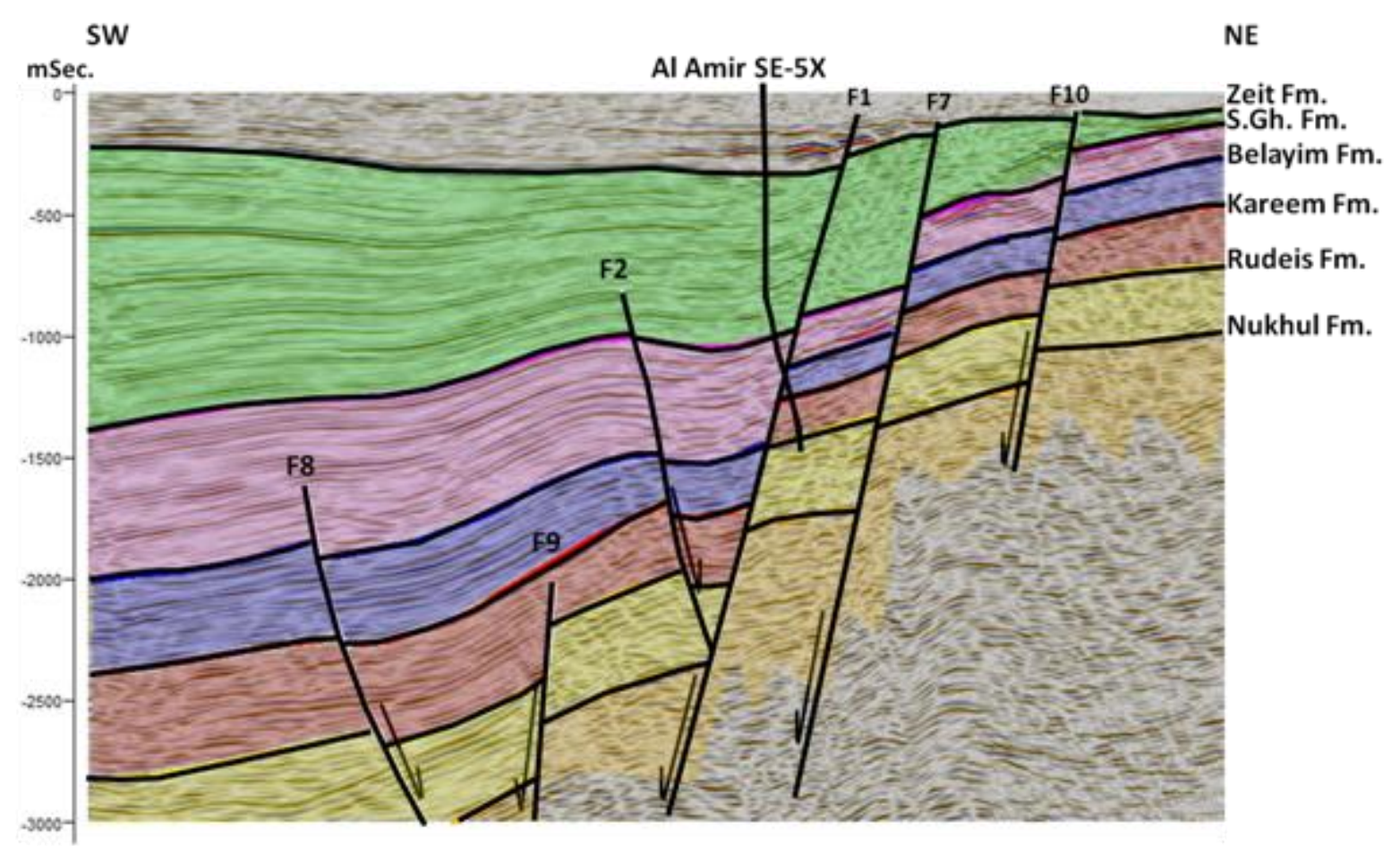

Fig. 4: Seismic section showing the SW dip of the study area and faults dissecting the mapped horizons. See Fig. 1 for location. 


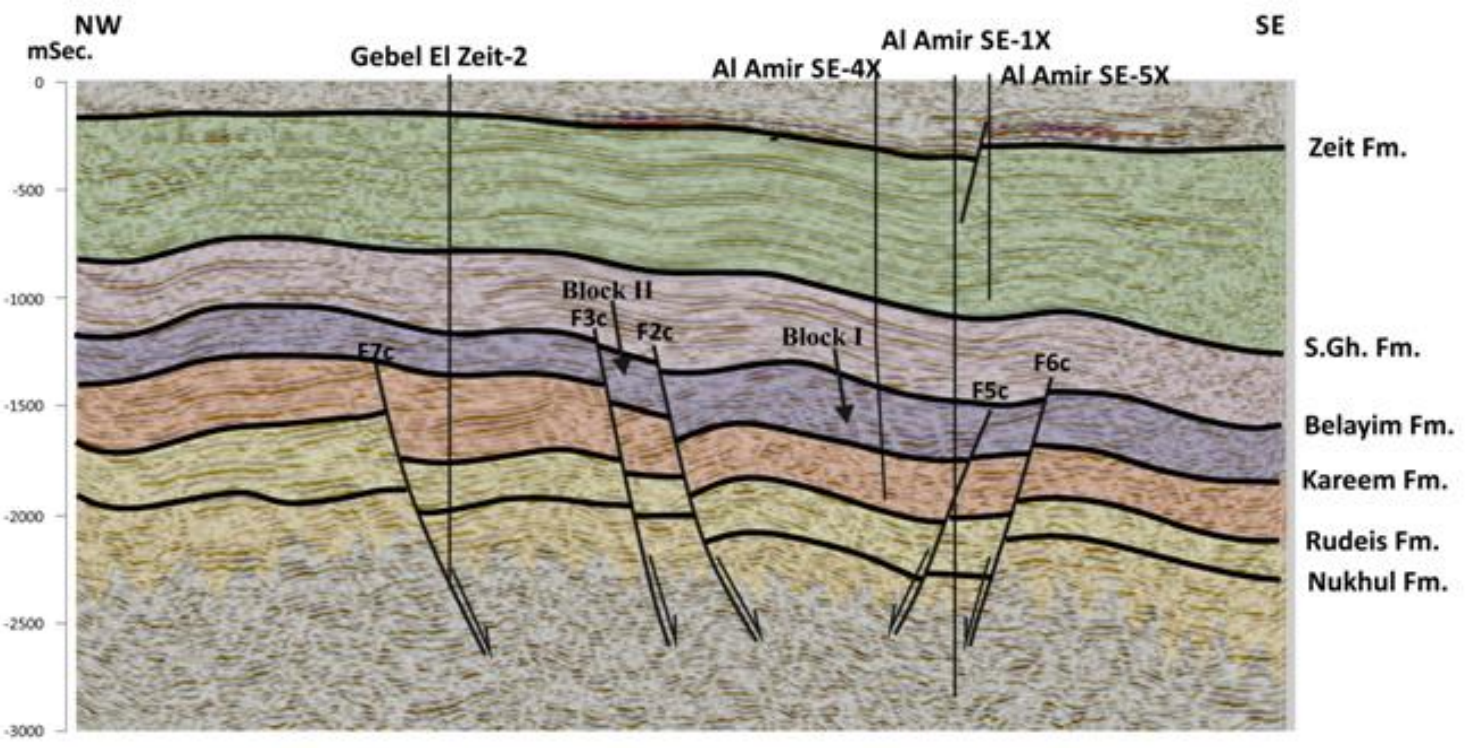

Fig. 5: Strike line showing the cross faults (F7c, F3c, F2c, F5c and F6c) in the study area. See Fig. 1 for location.

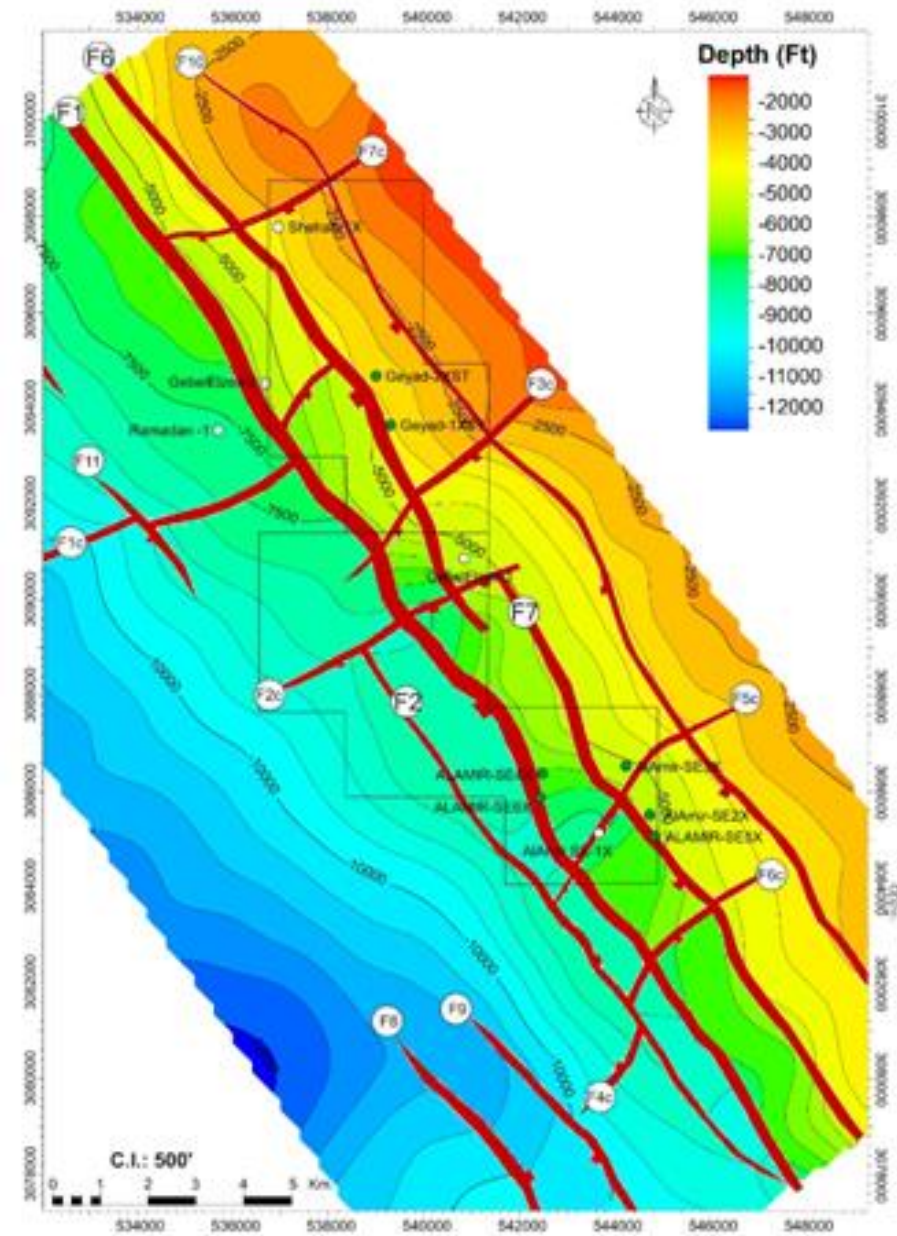

Fig. 6: Depth structure contour map on top Kareem Formation (Late Langhian).
Table 1: Maximum throws of the faults dissecting the Kareem Formation.

\begin{tabular}{|c|c|c|c|}
\hline & $\begin{array}{l}\text { Fault } \\
\text { Name } \\
\end{array}$ & $\begin{array}{c}\text { Max. } \\
\text { Throw (Ft) }\end{array}$ & $\begin{array}{l}\text { Direction } \\
\text { of Throw }\end{array}$ \\
\hline \multirow{8}{*}{ 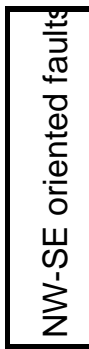 } & $\mathrm{F} 1$ & 2027 & SW \\
\hline & F2 & 148 & $\mathrm{NE}$ \\
\hline & F6 & 1553 & SW \\
\hline & F7 & 2203 & SW \\
\hline & $\mathrm{F} 8$ & 584 & $\mathrm{NE}$ \\
\hline & F9 & 667 & SW \\
\hline & F10 & 580 & SW \\
\hline & F11 & 305 & SW \\
\hline \multirow{7}{*}{ 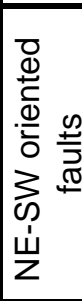 } & F1c & 625 & $\overline{S E}$ \\
\hline & F2c & 265 & SE \\
\hline & F3c & 874 & SE \\
\hline & $\mathrm{F} 4 \mathrm{C}$ & 135 & NW \\
\hline & F5c & 488 & SE \\
\hline & F6c & 959 & SE \\
\hline & F7c & 765 & SE \\
\hline
\end{tabular}




\section{Fault lengths}

Figure 7a shows the lengths of the rift-parallel faults at different stratigraphic levels from top Nukhul to top Zeit formations. Some faults die out within the Miocene section such as F8, F9 and F11 faults which die out in the Belayim Formation and F2 fault which dies out in the South Gharib Formation. Figure $7 \mathrm{~b}$ shows the lengths of the cross faults. These faults die out in the Belayim Formation except for faults F3C, F6C and F7C that die out in the South Gharib Formation.

\section{Maximum fault throws}

Figure 8a shows the throws of the rift-parallel (NNW-SSE) faults at the different Miocene levels. It shows two groups of faults, one with throws more than 1500' (F1, F6, F7 and F9) and another group with throws less than 1000' (F2, F8 F10 and F11). All of these faults show gradual decrease in throw upwardly indicating continuous movement on these faults during deposition of the Miocene syn-rift units. Some of these faults die out within the younger Miocene units such as faults F2, F8, F9 and F11.

Figure $8 \mathrm{~b}$ shows the throws of the cross faults at the different Miocene levels. It is obvious from this figure that all of these faults show gradual upward decrease in their throws indicating continuous movement during the deposition of the Miocene section they dissect. It is also clear that all cross faults die out within the South Gharib or Zeit Formation.

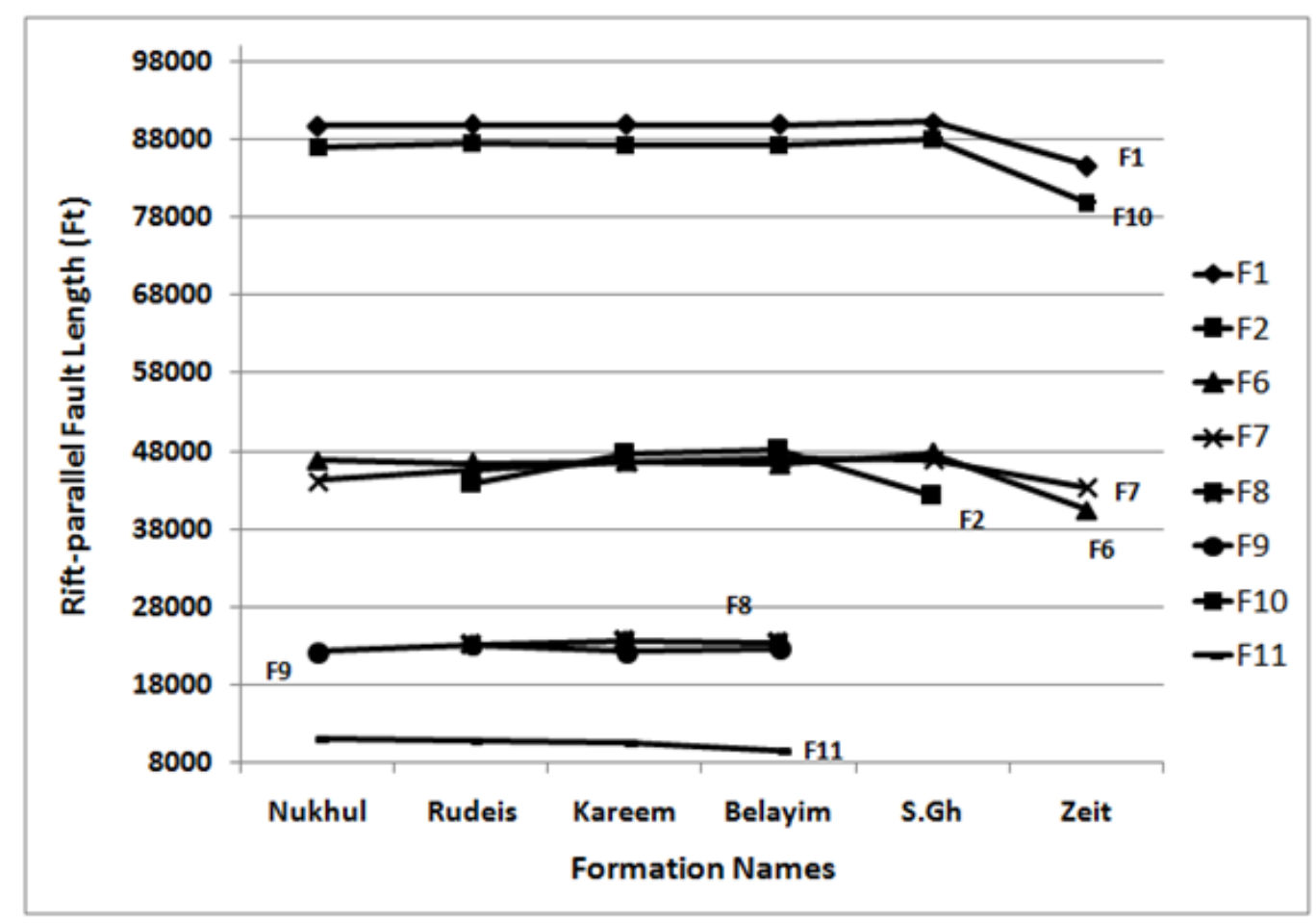

Fig.7a: Lengths of the rift-parallel faults. 


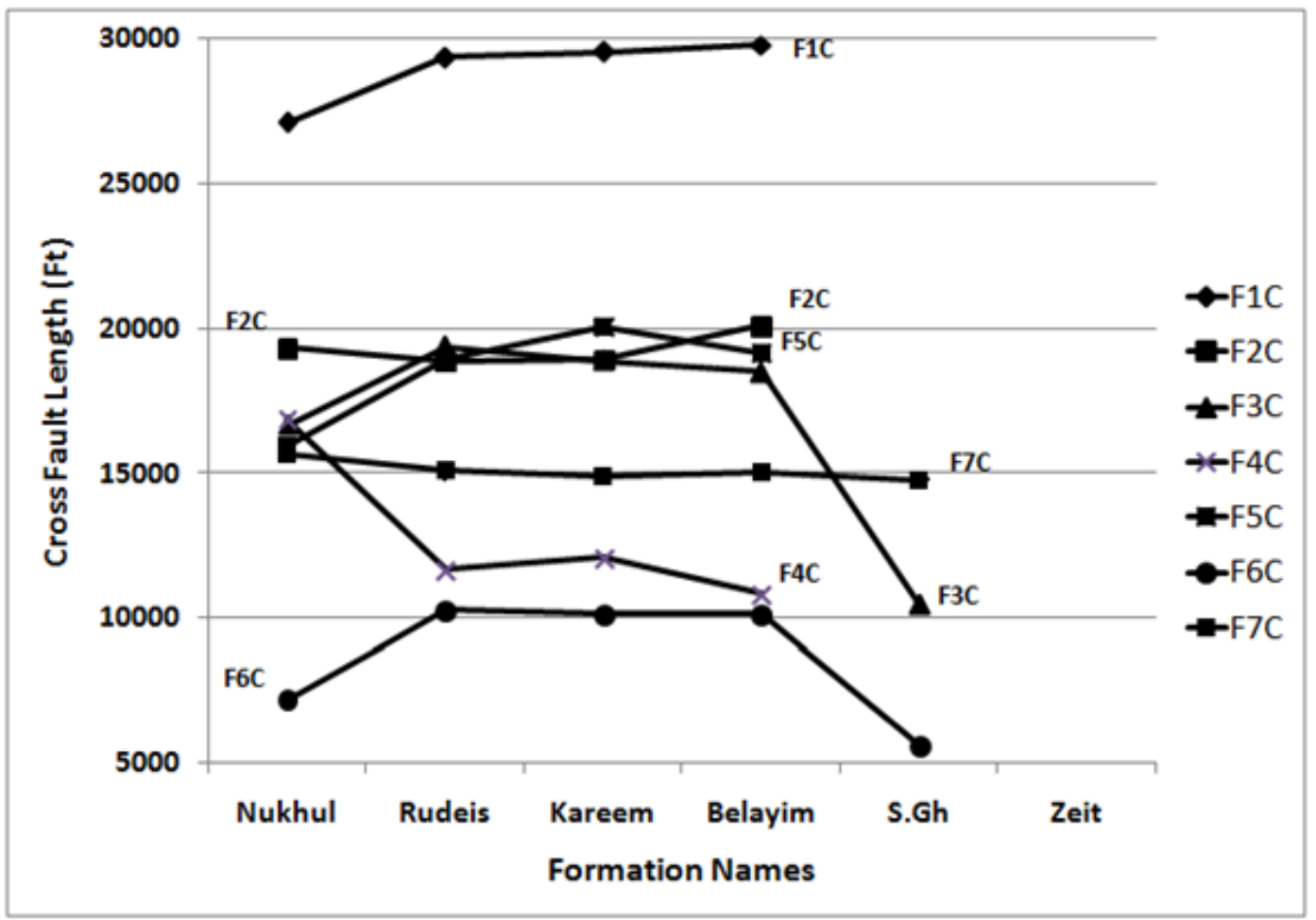

Fig.7b: Lengths of the cross faults.

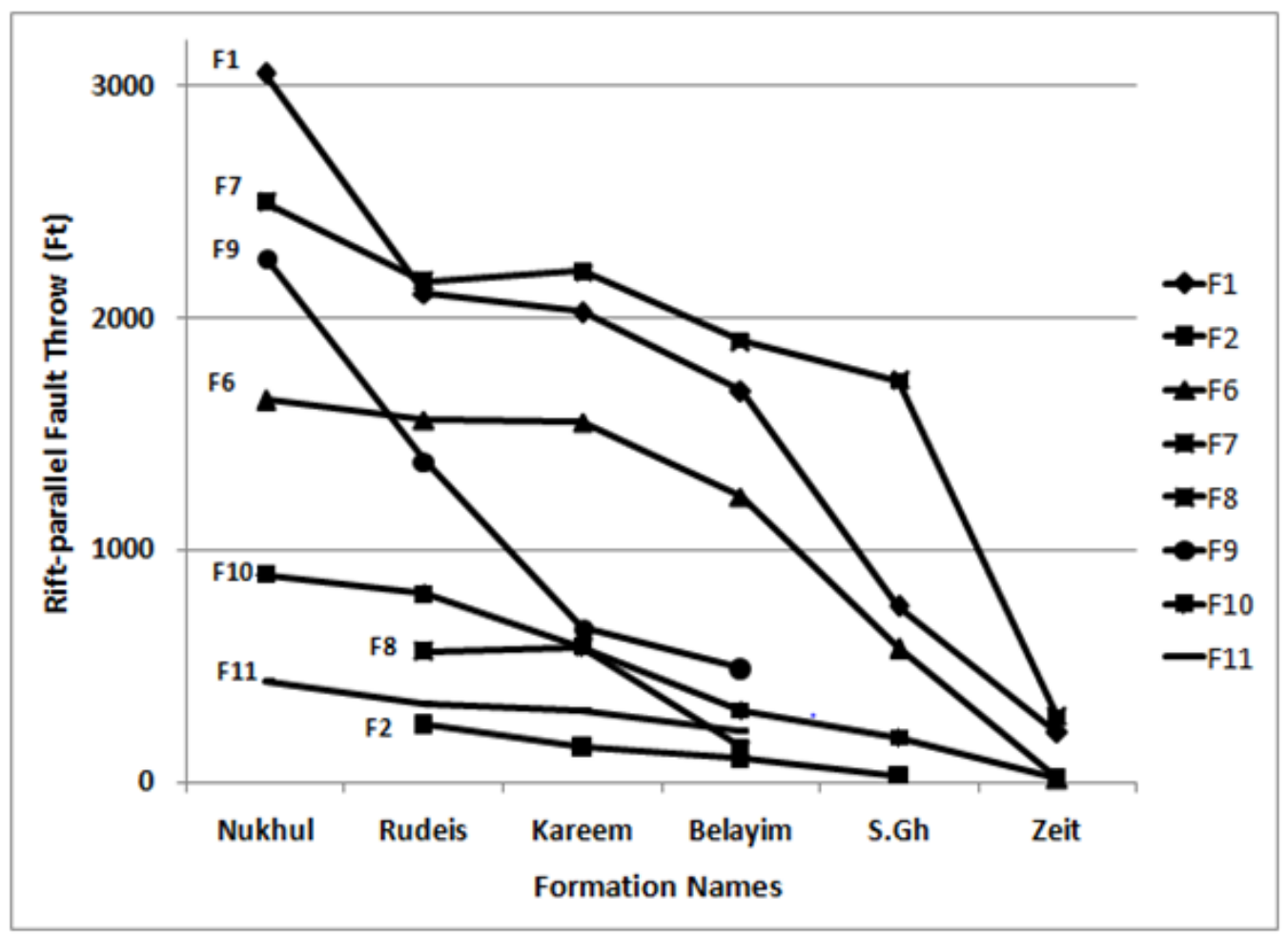

Fig.8a: Maximum throws of rift-parallel faults. 


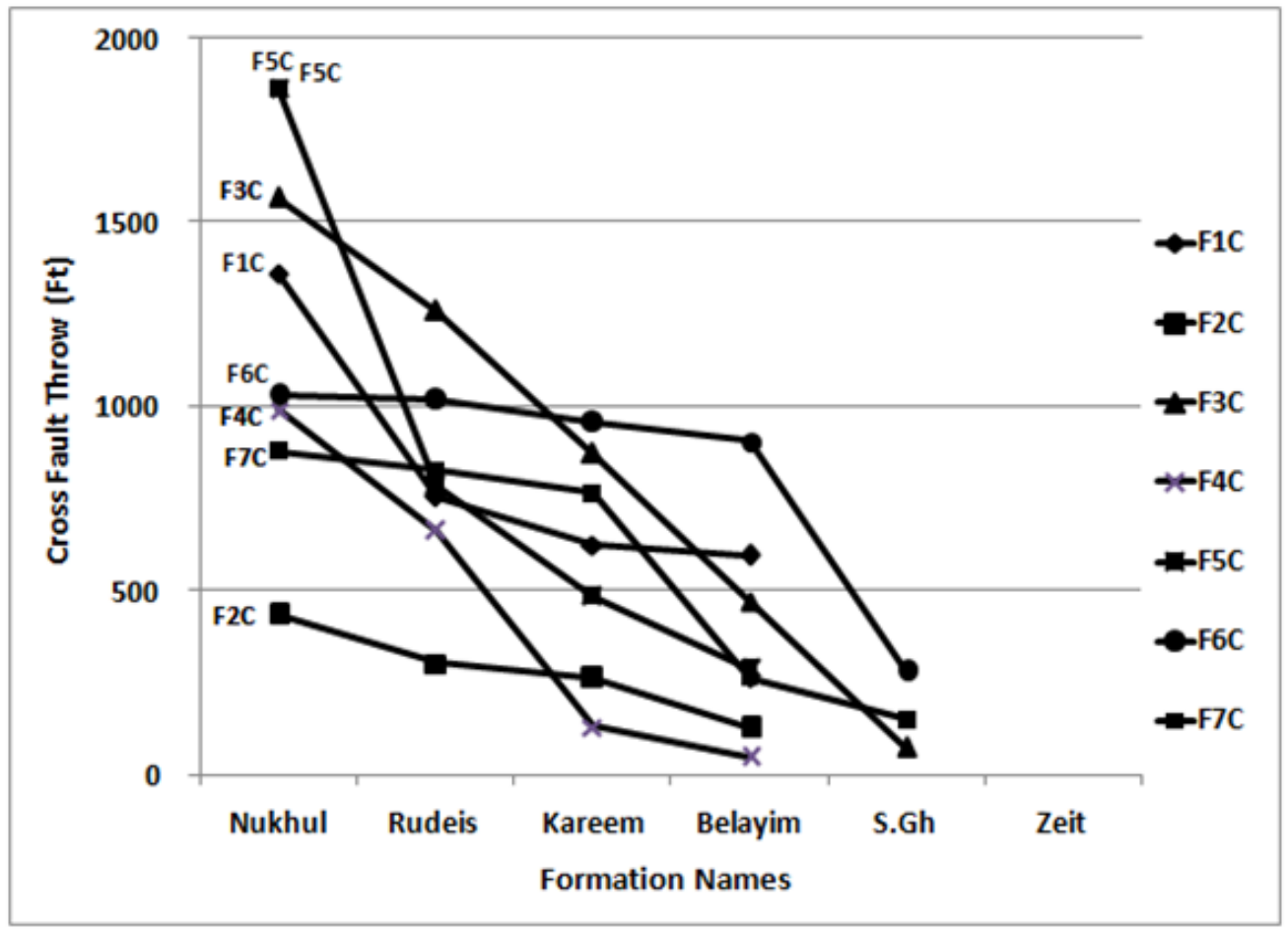

Fig. 8b: Maximum throws of cross faults.

\section{Tectonostratigraphy}

The supply of clastic sediments in the Kareem Formation came from the west from Esh El Mellaha Range (Moustafa and Khalil, 2017). The block diagrams in Figures 9 and 10 show the distribution of sand in the Al Amir and Geyad fields and the effect of the mapped faults on the sand distribution in the Kareem Formation. The sandstone of open marine inner to outer neritic facies of the Rahmi Member is distributed in Al Amir and Geyad fields with variable thickness from 17' in the north at Geyad-1Xst well up to $55^{\prime}$ in the south at Al Amir SE-6X well. Shehab-1X well location did not receive sands. The thicker sandstone occurs in Well-1 and Well-2, where the main fault F1 was active during the deposition, allowing accommodation for more sediment accumulation as a fan shape (Figure 9).

As for the Shagar member (Figure 10) the effect of cross faults (F1c, F2c and F3c) on sediments distribution is obvious. The sandstone of the Kareem Formation is restricted mainly to the Al Amir and Geyad fields. The sandstone in south Al Amir field is of deep marine, inner to outer neritic facies. The maximum sand thickness is in Al Amir SE-2X well (130') and minimum thickness occurs in Al Amir SE-4X well (23'). In the north Geyad field, the sandstone is deep marine, inner to outer neritic facies with thicknesses equal to 23' in both Shehab-1X and Well-1 as a fan shape. The sand occurrence and distribution change from NW to SE as shown in Figure 11. 


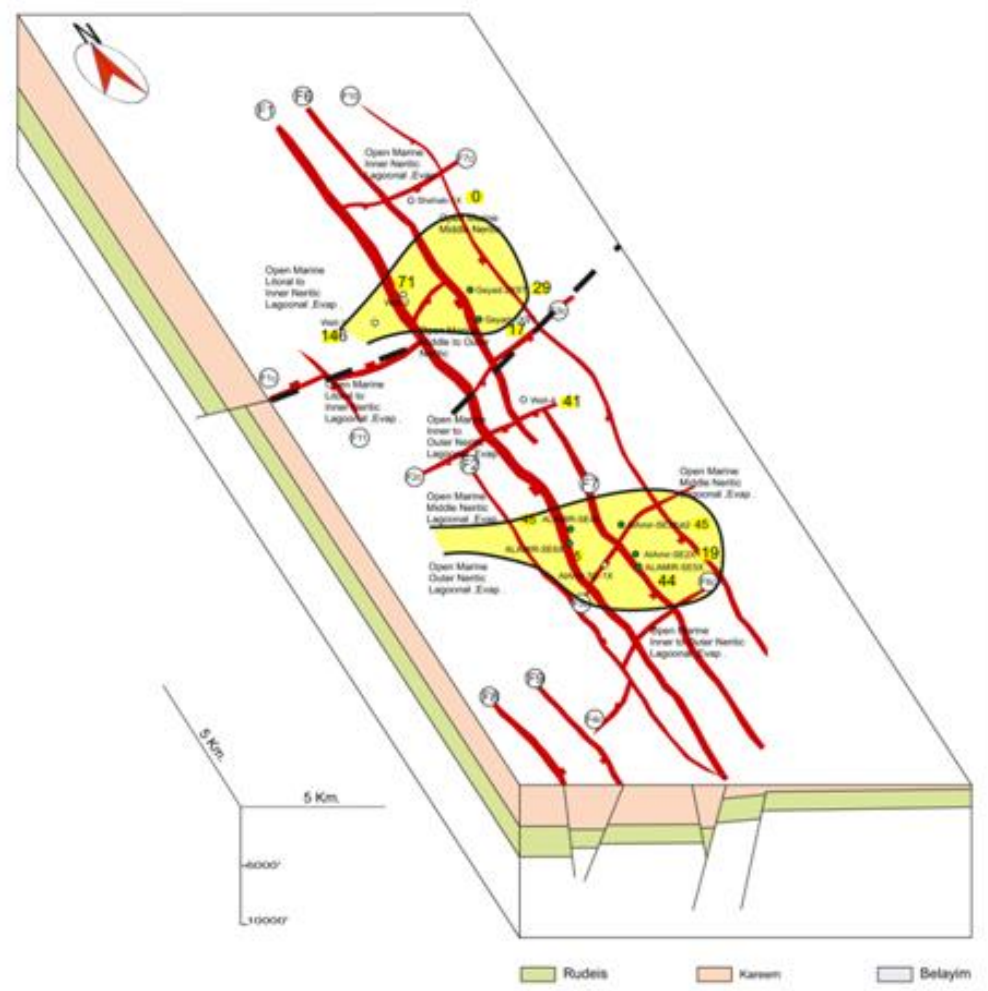

Fig.9: Block diagram for the study area showing the net sand of Rahmi Member in relation to the mapped faults.

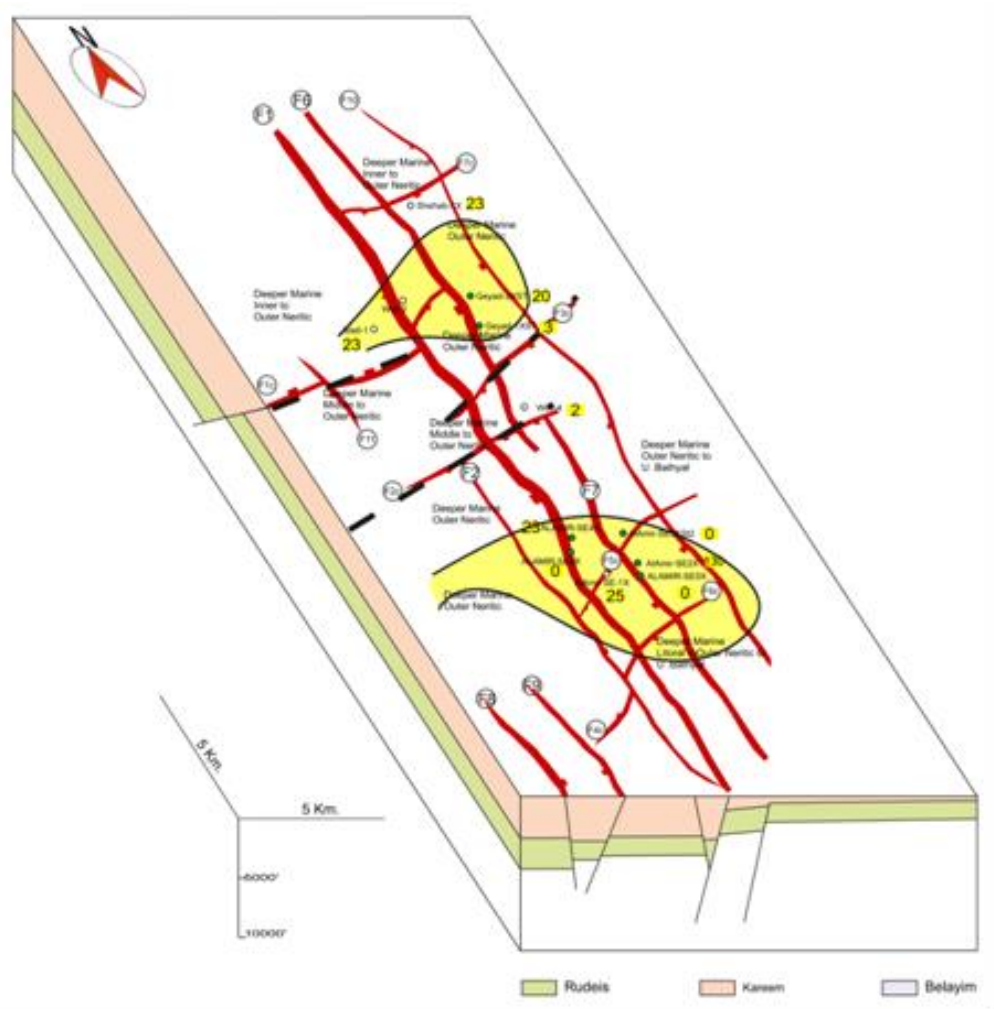

Fig.10: Block diagram for the study area showing the net sand of Shagar Member in relation to the mapped faults. 


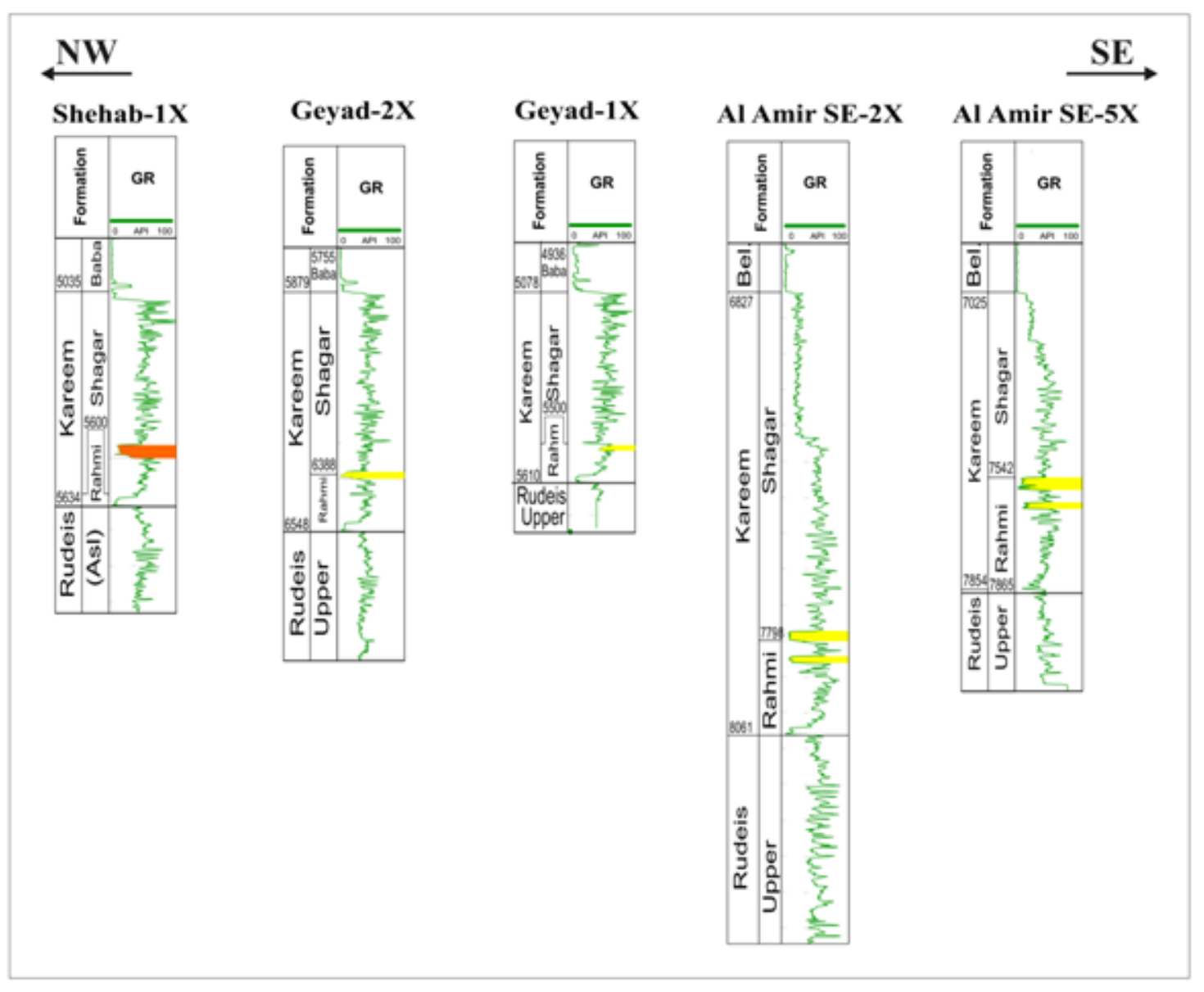

Fig.11: Sand distribution of the Kareem Formation (Rahmi Member) and thikness increase from NW to SE.

\section{Conclusion}

Using the interpretation of seismic data, the detailed structural mapping of $\mathrm{Al}$ Amir and Geyad fields indicates the SW dip of the Miocene rock units toward Esh El Mellaha fault that bounds the down dip area of the West Zeit (Gemsa) basin. The rift-parallel and cross faults dissecting the Miocene sediments show continuous slip during the Miocene time. The distribution of sand in the Kareem Formation which represents the oil-bearing reservoir unit in the two fields is controlled by the rift-parallel and cross faults which offered space for accommodation of these sands on their downthrown sides. The Kareem sands represent two fans fed from the SW by the main wadis draining the structural highs of Esh El Mellaha block.

\section{Acknowledgements}

We would like to thank the EREX Petroleum Consultants team. We also thank the Egyptian General Petroleum Corporation for providing the data used for this study. 


\section{Refrences}

Colletta, B., Moretti, I. and Chenet, P.Y. 1985, Structure of the Gabal Zeit region, Gulf of Suez, Egypt, a field example of tilted block-crest. Institut Francais du Petro, Ref. I.F.P. 33525, 56 p.

Darwish, M, and El Araby, A., 1993, Petrography and diagenesis aspects of some siliciclastic hydrocarbon reservoirs in relation to rifting of the Gulf of Suez, Egypt. Geol, Soc. Egypt., Spec. Pub. No. 1, p. 155-187.

Dolson J. C., Shann M.V., Hammoudah, Rashed, R. and Matbouly, S., 2000, The Petroleum potential of Egypt. Second Wallace E. Pratt memorial Conference "Petroleum Provinces of the $21^{\text {st }}$ Century" January12-15, 2000 San Diego, California.

Evans, A. L. 1988, The sedimentary evolution of the Suez rift basin, Egypt: Neogene paleobathymetry, subsidence and uplift history, tectonic and stratigraphic events. PhD thesis, Stanford University, $228 \mathrm{p}$.

Haq, B.U., Hardenbol, J. and Vail, P.R., 1987, Chronology of fluctuating Sea Levels since the Triassic. Science, v. 235, p. 1156-1167.

McClay, K.R., Nichols, G.J., Khalil, S.M., Darwish, M. and Bosworth, W., 1998, Extensional tectonics and sedimentation, Eastern Gulf of Suez, Egypt. In: Purser, B.H. and Bosence D. W. (eds.) Sedimentation and Tectonics in Rift Basins: Red Sea - Gulf of Aden. Chapman and Hall, London, p. 223-238.

Moon, F.W., and Sadek, H., 1923, Preliminary geological report of Wadi Gharandal area (north of Gebel Hammam Faraun, Western Sinai). Petroleum Research Bull. No. 12, Government press, Cairo, 42 p.

Moustafa, A.M., 1976, Block faulting in the Gulf of Suez. $5^{\text {th }}$ E.G.P.C. Exploration Seminar, Cairo, Egypt. 20 p.

Moustafa, A.R., 1993, Structural characteristics and tectonic evolution of the east margin blocks of the Suez rift. Tectonophysics, v. 223, p. 381-399.

Moustafa, A.R., 2002, Controls on the geometry of transfer zones in the Suez rift and northwest Red Sea: implications for the structural geometry of rift systems. AAPG Bull., v. 86, p. 979-1002. 
Moustafa, A.R. and Fouda, H.G., 1988, Gebel Sufr El Dara accommodation zone, southwestern part of the Suez rift. Middle East Research Center, Earth Science Series, Ain Shams University, v. 2, p. 227-239.

Moustafa, A.R. and Khalil, S., 2017, Control of extensional transfer zones on syntectonic and posttectonic sedimentation: Implication for hydrocarbon exploration. Journal of the Geological Society (London), v. 174 , p. 318-335.

NSSC National Stratigraphic Sub-Committee, 1964, Stratigraphic SubCommittee of the National Committee of Geological Sciences, Miocene rock stratigraphy. Egyptian Journal of Geology, v.7.

NSSC National Stratigraphic Sub-Committee, 1974, Stratigraphic SubCommittee of the National Committee of Geological Sciences of Egypt, Miocene rock stratigraphy of Egypt. Egyptian Journal of Geology, v. 18, p. 1-69.

Patton, T.L., Moustafa, A.R., Nelson, R.A. and Abdine, A.S., 1994, Tectonic evolution and structural setting of the Gulf of Suez rift. In: London, S. (ed.) Interior Rift Basins. AAPG Memoir 59, p. 9-55.

Sakran, S., Nabih, M., Henaish, A., and Ziko, A., 2015, Structural regime and its impact on the mechanism and migration pathways of hydrocarbon seepage in the southern Gulf of Suez rift: An approach for finding new unexplored fault blocks. Marine and Petroleum Geology, v. 71, p. 55-75. 


\section{البناء التركيبي تحت السطحى لحقلي الأمير وجياد ، الجزء الجنوبى الغربي لأخدود خليج السويس ، مصر فيز}

أحمد عبد الستار ميهوب1 ، عادل رمضان مصطفى2 ، محمد يوسف رزق22 ، سمير محمد زلط3 1 : شركة ايريكس ، 2: قسم الجيولوجيا - جامعة عين شمس ، 3: شركة بترو أمير

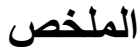

تقع منطقة الدر اسة جنوب خليج السويس وتشمل حقل الأمير وحقل جياد. وتقع منطقة الدراسة غرب جبل الزيت وتغطي حوالي 321 كم². وتعتمد الدراسة علي تحليل البيانات السيزمية ثنائية الابعاد و أيضا علي البيانات المستخرجة من الأبار في منطقة الدراسة. وباستخدام أسطح الإنعكاس (2D) السيزمية تم تحديد وتمييز ستة أسطح من مكونات الميوسين وتم عمل خرائط لهذه الأسطح من سطح

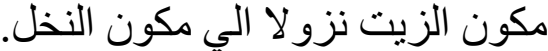
وتتميز منطقة الدراسة بوجود صدوع ذات إتجاه شمال غرب - جنوب شرق موازية لأخدود خليج السويس والتي تميل بإتجاه الرمية الي جنوب غرب. وتقطع هذه الصدوع بأخرى ذات إتجاه شمال شرق - جنوب غرب حيث تكون حدود الحقلين (الأمير ، جياد). وتبرز الدراسة تأثثر هذه الصدوع ذات الإتجاه شمال شرق - جنوب غرب في توزيع الرواسب في مكون الكريم الترسيبي. 